\title{
Magnesium Transporter Protein 1
}

National Cancer Institute

\section{Source}

National Cancer Institute. Magnesium Transporter Protein 1. NCI Thesaurus. Code C157563.

Magnesium transporter protein 1 (335 aa, $38 \mathrm{kDa}$ ) is encoded by the human MAGT 1 gene. This protein is involved in magnesium ion transport an $\mathrm{N}$-glycosylation of proteins. 